\title{
En torno a la definición de imagen como representación de la realidad
}

\section{On the definition of image as a representation of reality}

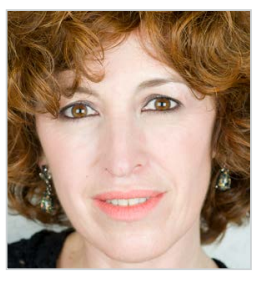

Alejandra Walzer Moskovic. Profesora Titular del Departamento de Comunicación de la Universidad Carlos III de Madrid donde enseña Teoría de la imagen. Además es Directora del Grupo de Cooperación UC3M: Memoria e imagen de los pueblos de África, dedicado a la etnografía audiovisual en el ámbito del África Subsahariana. Principales líneas de investigación: imagen y cultura; socio antropología del cuerpo y sus imágenes; medios de comunicación y educación; epistemología de la comunicación. Autora de: “¿Qué es un niño hoy? Reflexiones sobre el cambio” (2012) Ed. Comunicación Social; "Visiones, saberes y placeres. Sobre cultura visual y educación" (2011) Ed. Universitas; "La belleza. De la metafísica al spot" (2008) Ed. Octaedro; El tatuaje contemporáneo ¿entre el arcaísmo y la moda? (2019) Revista Aisthesis de investigaciones estéticas; "El arte en el discurso de los tatuadores" (2015) Revista Arte, Individuo y Sociedad, UCM; Vol. 27, No 3.

Universidad Carlos III de Madrid, España

alejandra.walzer@uc3m.es

ORCID: 0000-0002-2244-0520

Recibido: 22/02/2021 - Aceptado: 31/05/2021 - En edición: 27/07/2021 - Publicado: 01/12/2021 Resumen:

Este ensayo se propone interrogar y discutir la definición canónica que se emplea para hacer referencia a las imágenes visuales y que enuncia que toda imagen es una representación de la realidad. El objetivo es matizar desde diversas perspectivas la definición que tan habitualmente se emplea en la enseñanza de las disciplinas visuales y comunicativas. Para hacerlo se aborda la naturaleza diversa de las imágenes diferenciando las imágenes matéricas, las indexicales y las digitales o e-imágenes, buscando establecer las diferentes relaciones que las imágenes que podemos ubicar en cada una de estas categorías pueden tener con la realidad y con la materialidad. También se explora la diferencia entre imágenes diversas según el campo al que pertenezcan trazando distinciones, por ejemplo, entre las del periodismo y las del arte. Por último se interroga la naturaleza de la realidad virtual y de la realidad aumentada para repensar no solo la definición referida sino para abordar la naturaleza de lo visual en el escenario actual.

\section{Palabras clave:}

Imagen visual; imagen digital; realidad; realidad aumentada; materialidad.
Received: 22/02/2021 - Accepted: 31/05/2021 - Early access: 27/07/2021 - Published: 01/12/2021 Abstract:

This essay aims to examine and discuss the canonical definition used to refer to visual images, which states that every image is a representation of reality. The purpose is to qualify from different perspectives the definition that is so commonly used in the teaching of visual and communicative disciplines. To do so, the diverse nature of images is addressed, differentiating between material images, indexical images and digital or e-images, seeking to establish the different relationships that the images from these categories have with reality and with materiality. It also explores the difference between diverse images according to the field to which they belong, drawing distinctions, for example, between those of journalism and those of art. Finally, the nature of virtual reality and augmented reality is questioned in order to rethink not only said definition, but also to address the nature of the visual in the current scenario.

\section{Keywords:}

Visual image; digital image; reality; augmented reality; realism; materiality.

Cómo citar este artículo:

Walzer Moskovic, A. (2021). En torno a la definición de imagen como representación de la realidad. Doxa Comunicación, 33, pp. 39-51. https://doi.org/10.31921/doxacom.n33a924 


\section{Introducción}

¿Qué es una imagen visual? Esta pregunta resulta ineludible en cualquier clase de arte o de audiovisuales, sin embargo, teniendo en cuenta la preminencia generalizada de lo visual en la expresividad y en la comunicación contemporáneas, podríamos sugerir la conveniencia y pertinencia de abordar esta pregunta en todos los ámbitos educativos posibles puesto que la reflexión sobre las imágenes abarca desde la publicidad a la política, desde el ocio a la ciencia, desde las comunicaciones personales a las comunicaciones sociales, etc. Pensar las imágenes, por tanto, es una tarea que puede ser abordada como una contribución a la reflexión sobre la cultura, la sociedad, las formas de vida, la libertad. Este texto es una propuesta para repensar la respuesta canónica que de modo habitual y desde hace muchas décadas se usa cuando nos proponemos responder a la pregunta por la naturaleza de las imágenes visuales, a saber: una imagen es una representación de la realidad.

Por lo general, y seguramente con acierto, se transmite la idea de que representar es volver a presentar algo: re-presentarlo, y también que toda representación lo hace de una certa maniera. Representar es un acto viable mediante el uso de los recursos de un lenguaje, en este caso, el lenguaje de las imágenes, que tiene elementos y códigos expresivos, gramática, poética, etc. La representación no se confunde con el objeto de la representación puesto que ambos tienen una existencia diferenciada, una sustancia heterogénea, funciones específicas, una temporalidad diversa. Al hilo de estas conceptualizaciones, siempre es oportuno señalar que, a pesar de esta evidencia tan aplastante y de sencilla demostración, hay frecuentemente una tendencia a confundir a las imágenes del mundo con las realidades del mundo. La fuerza expresiva de las imágenes puede ser impactante y persuasiva como se constata en el hecho de que las imágenes religiosas sean fuente de adoración y temor durante siglos o que en los inicios del cine, los recién estrenados espectadores de las imágenes en movimiento, se pusieran de pie dispuestos a alejarse a la carrera cuando en la pantalla de los hermanos Lumiere se proyectaban imágenes de un tren entrando en la estación. Con el acostumbramiento de los públicos a vivir en un entorno de gran densidad visual, se ha producido un cierto aprendizaje sobre la naturaleza de lo imaginístico, pero eso no ha eliminado la fuerte simbiosis existente entre las imágenes y la realidad que históricamente ha prevalecido, se trata de un cierto carácter ectoplasmático en virtud del cual una imagen puede ser tomada por sustituto vicario de una cierta realidad o persona. Además, como señala Sontag en su texto sobre la fotografía (2008) la tendencia a interpretar la realidad a través de lo que las imágenes nos ofrecen es muy real, y aun si desde la antigüedad filósofos como Platón han intentado erosionar esa simbiosis propugnando una aprehensión de la realidad despojada del peso de aquello que lo visual aporta, sin embargo, tras siglos de "batalla de las imágenes"(Gubern, 1999:51), ni las disquisiciones filosóficas ni el posterior humanismo, ni el pensamiento científico en avance mitigaron la fuerza persuasiva de lo visual, su carácter vívido, su potencial realismo, su apariencia de realidad.

Poco podemos conocer sobre la reacción que generaban las expresiones visuales en el paleolítico, pero sí sabemos que durante siglos la potencia de lo visual ha servido a múltiples fines, sean éstos de orden mágico, de adoración, de defenestración, de narración, incluso de demostración, de exaltación de lo bello o de todo lo contrario. Cierto es que, desde que la fotografía trajo su movilizadora novedad a la que se añadió la posterior invención del cine, los medios de registro y comunicación de lo visual se dotaron de un halo especialmente impactante de autenticidad. Si existe registro visual de algo y ese registro se ha hecho por medios mecánicos, es de suponer que ese evento ha tenido lugar frente a la mirada de alguien que operaba una cámara. 
En la actualidad, la digitalización junto con la multiplicación de recursos para la creación, y de canales para la emisión de imágenes, ha introducido la necesidad de formular las preguntas otra vez puesto que un buen número de actividades ocurren y transcurren en espacios virtuales que generalmente se manifiestan en pantallas y que tienen un altísimo componente visual cuya fuente puede ser múltiple: desde un archivo generado en una cámara hasta el puro diseño emergido en el seno de la ejercitación de las claves del lenguaje computacional, sin una existencia matérica antecedente.

En relación con la multiplicidad de opciones para la ejecución y difusión de creaciones visuales, la idea de audiencias o de espectadores resulta ahora, cuanto menos, una denominación incompleta que sólo es capaz de abarcar uno de los aspectos de nuestros modos de estar y relacionarnos con las imágenes. Hoy casi todos, además de públicos somos productores de imágenes, y lo somos en una medida incomparable a la de etapas precedentes, pero además podemos ser visitantes y frecuentar, como si de un nuevo hábitat se tratara, diversos espacios de naturaleza virtual que pueden producir efectos de realidad. Lo digital y la digitalización se han extendido hacia infinidad de entornos. La transición hacia lo digital es un propósito estratégico de gobiernos, administraciones, empresas, sistemas educativos, la ciencia, y también de las artes y las comunicaciones, entre otros.

Lo digital implica un universo durmiente: no se activa hasta que no pongamos en funcionamiento los mecanismos por los que el código será leído y, en consecuencia, transformado en algo visible en la pantalla. En su corazón, la imagen digital es una composición binaria ininteligible, pero su virtud es estar siempre disponible a despertar en los dispositivos respondiendo a una sola orden: clic, y con el clic se hace la luz, que es otra forma de aludir a la imagen.

Las imágenes cambian y nos cambian de modo que interrogar al propio concepto de imagen como representación de la realidad que se puede encontrar en innumerables textos y que se repite en incontables salas de clase, parece lógico y también necesario. El objetivo de este ensayo no es proponer una nueva definición de imagen visual y, mucho menos, de realidad sino poner en perspectiva y actualidad la definición canónica. Quizás para abandonar la idea o incluso la necesidad de encontrar una fórmula omnicomprensiva.

\section{La imagen como representación de la realidad y la cuestión del realismo}

La mediatización de nuestras vidas y la disponibilidad perpetua de tecnologías domésticamente accesibles para la producción, distribución y visionado de imágenes a lo que ha de añadirse lo que lo que de forma inquietante se llama: realidad virtual y realidad ampliada -todo derivado en definitiva de la digitalización- nos obliga a preguntarnos no sólo por la capacidad representativa de las imágenes sino también por la naturaleza de la realidad referencial que supuestamente esas imágenes representarían. La pregunta no es nueva y ha intentado responderse de diversos modos, que no solo estuvieron moldeados por la perspectiva epistemológica desde la que se aborda sino también por las diferentes etapas que ha tenido la producción de imágenes. Ese devenir exige consideraciones específicas.

Para comenzar, es preciso indicar que nuestra mirada sobre el asunto tiende a estar permeada por una perspectiva platónica que asume que las artes, a diferencia de la filosofía, sirven para imitar y solo pueden producir meras ilusiones, apariencias de las cosas sin alcanzar la verdad puesto que ésta es suprasensible y corresponde al mundo de las ideas. Las imágenes, en tanto se sitúan en el plano de lo sensible, de lo cambiante, lo potencialmente engañoso y particular, no serían aptas para alcanzar el conocimiento verdadero que es universal. La pregunta por el valor de las imágenes atraviesa la historia del pensamiento occidental 
desde entonces hasta la actualidad sorteando numerosos meandros y acarreando nuevas aguas. La pretendida debilidad de las imágenes se topa con la evidencia de que su fuerza expresiva es capaz de generar misterios, efectos de verdad y de persuasión. Las imágenes son un bien preciado.

Cierto es, como señala Hans Belting (2007), que en el auge del debate sobre las imágenes que periódicamente resurge, se tiende a hablar de la misma forma de distintas imágenes generando una pugna por obtener el monopolio de la definición, o podíamos decir: en la búsqueda de una definición única. ¿Es posible pensar de la misma forma las imágenes de las artes plásticas, las de las artes visuales, las de los medios de masas, las de redes sociales, las de tipo documental, periodístico, el dibujo infantil etc.? En principio, parecería poco prudente aunque sin embargo, también sería válido aseverar que la imagen, en tanto lenguaje diferenciado, tiene características propias aislables y definibles y que los medios y fines para los que se use modulan u orientan el uso de ese lenguaje. ¿Qué es una imagen visual?

Vayamos al diccionario como punto de partida elemental para recoger la traducción académica de los usos. Consultamos al de la Real Academia de la Lengua Española y al echar un ojo a la definición de la palabra imagen encontramos que este sustantivo alude a: “figura, representación, semejanza y apariencia de algo". La lectura desata la crítica inmediata porque ya sabemos que los términos semejanza y la apariencia no son esenciales o exigibles. El admirado Gombrich discutió por razones idénticas al diccionario -en su caso el de Oxford- en sus "Meditaciones sobre un caballo de juguete" (Gombrich, 1999), y estableció las diferencias entre representación, sustitución, imitación, semejanza. No volveremos a referir lo que ya está bien planteado, pero sí tenemos

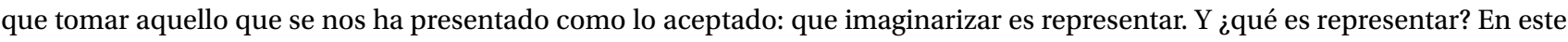
caso, la definición que obtenemos resulta tautológica respecto de nuestro interrogante que dice que el verbo transitivo representar, consiste en: "hacer presente algo con palabras o figuras que la imaginación retiene". Tomamos con interés el "algo" de la nueva definición porque, a los fines de nuestra pregunta es, al menos en principio, más interesante que "realidad". Diríamos que la indefinición de ese "algo", frente a la arrogante presunción de clarividencia de la palabra "realidad", deja lugar a la imaginación, a la variedad, a cierta indeterminación. "Algo" puede flotar, "realidad”, en cambio, cae fuerte, con peso platónico.

Así, en esta primera alusión, empezamos a sopesar que la balanza de lo problemático al pensar sobre lo que una imagen visual es, parece inclinarse haciendo caer lo denso del lado del término "realidad", término que suscita una asociación con la materialidad de lo visible, de lo sucedido, de lo tangible, incluso de lo unívoco.

La imagen no es la realidad y la realidad no es la imagen. La imagen es una representación de la realidad, de una realidad. Phillipe Dubois explica que "toda reflexión sobre un medio cualquiera de expresión se ve en la obligación de plantear la cuestión fundamental de la relación específica que existe entre el referente externo y el mensaje producido por dicho medio" (Dubois, 2008:21) En el entendimiento de que toda imagen representa una realidad, se ha establecido que en función de las características propias del lenguaje visual, si la imagen tiene componentes altos de iconicidad, mayor será su cercanía con la realidad que representa. Ello es así dado que la imagen tiene una cualidad específica que no comparte con otros lenguajes: su capacidad para generar parecidos con sus referentes. Ni la escritura musical ni la lingüística, por ejemplo, comparten esta naturaleza puesto que sus códigos expresivos son de naturaleza arbitraria. En el campo visual, la posibilidad de moverse en el terreno de la similitud o la falta de ella es facultativa y en cuanto empezamos a internarnos por los senderos de la abstracción se van perdiendo los indicios de lo reconocible, se va diluyendo la capacidad evocadora, generando así algo distinto, más desapegado del objeto que la origina y 
más enigmático en su desciframiento para quien la observa que, en ocasiones, se descubre comprometido a posicionarse como hermeneuta respecto a la imagen que mira.

Pero ¿quién certifica que la realidad deba necesariamente referirse a aquello que tiene una existencia visible, es decir: evidencia? El pintor David Hockney apunta con precisión que el de realidad "es un concepto escurridizo, porque no es externo a nosotros" (Hockney y Gayford: 2018:23) Afirmamos, por tanto, que la realidad es también interna y que concierne en buena medida a quienes hacen las imágenes, pero también a quienes las miran. Ambos comparecen con una realidad inalienable: la de su subjetividad, su contexto, su tiempo. Quien crea una imagen lo hará indisolublemente con su particularidad sensible, intelectual, cultural, psicológica, con su talento, su propia trayectoria artística o profesional, sus inclinaciones, sus filias artísticas, sus fobias, etc. El factible desencuentro entre la idea plasmada en la obra por un artista y la interpretación o las emociones que suscita en la persona que observa, nos sitúa no solo en planos de realidades diferentes sino también en experiencias potencialmente muy disímiles respecto de la realidad representativa a la que alude la obra.

En numerosos textos sobre historia de las artes visuales se sitúa el punto de ruptura o desencuentro entre realidad y representación en los movimientos de vanguardia y en la abstracción pictórica (desde finales del siglo XIX), sin embargo, raramente se cuestiona la naturaleza de la realidad que se representa en la pintura clásica, medieval o renacentista, plagada de ángeles, seres inmateriales, personajes mitológicos, divinidades benéficas o satánicas que nadie ha visto jamás salvo en sueños o alucinaciones ¿Qué relación tiene el realismo o la apariencia de realismo con la realidad? En el cuadro pintado por Goya "Saturno devorando a su hijo", por citar un ejemplo, obtenemos imágenes de apariencia conmovedoramente realistas pero la realidad que allí se representa pertenece al registro de lo mitológico y como tal, al relato. El cuadro puede albergar adicionalmente un contenido crítico de naturaleza política o social, pero el título, en principio, ancla el sentido conduciéndonos en la dirección que nos hace tomar a la pintura, al menos, como la representación de un personaje mitológico en un acto de canibalismo muy específico.

Quizás deberíamos considerar la idea que propone Hockney cuando afirma que: "todo texto es ficción en alguna medida, ¿cómo no? Lo mismo ocurre con las imágenes. Ninguna de ellas representa sin más la realidad" (Hockney y Gayford: 2018:24) La mimesis que se atribuía a las artes visuales de la pintura y la escultura por su capacidad de generar similitud (vera icon) podría, en lo que atañe a su esencia, ser a nuestro entender tan virtual, tan vicaria, como lo es la realidad en un cuadro abstracto. Eduardo Ripoll Perelló (1986) explica en su obra sobre el arte paleolítico, que si dejamos de lado las imágenes zoomórficas y nos centramos en las imágenes abstractas que se encuentran en numerosas cuevas, veremos que ya en los albores de la creación icónica la producción de formas simbólicas, no miméticas, era posible. Estas imágenes aportaban un factor abstracto y, en consecuencia, requerían una capacidad de lectura superior a la que se necesita para el arte naturalista. Seguramente, los secretos para iniciados en los misterios de los símbolos habitaba en esas imágenes que no se parecen a las cosas.

Y ya, por fin, cabe recuperar algo que es esencial al lenguaje visual y su naturaleza abstractiva: más allá del preciosismo representacional que ciertas imágenes nos ofrezcan, más allá de la habilidad de un artista para crear vívidamente el espacio de la escena en la imagen, la puntilla de un vestido o los matices de un rostro, todas ellas son bidimensionales. La bidimensionalidad inherente a las imágenes es algo que no existe en el plano de la naturaleza o de las cosas materiales y, esa condición en sí alberga ya un grado de abstracción esencial que no solo afecta a la pintura sino también a la fotografía que se ha tenido por un arte figurativo de alta fidelidad. 


\section{Imágenes manuales, indexicales y digitales: la desmaterialización}

La ciencia situaba en alrededor de treinta mil años atrás el comienzo de la actividad de producción icónica y era atribuida a la especie Homo sapiens. Sin embargo, esta información se ha ido actualizando a medida que los hallazgos y las técnicas de datación consiguieron arrojar nueva evidencia. La revista Science ha publicado en 2018 una investigación en la que un equipo de científicos establece que algunas pinturas rupestres encontradas en cuevas españolas de Cantabria, Málaga y Cáceres datan de hace más sesenta mil años, por tanto, antes de que los sapiens dominaran Eurasia, de lo cual se deduce -contrariando a las teorías vigentes- que los neandertales poseían ya capacidad simbólica y habilidad material para crear imágenes estables fuera de su mente (Hoffman et al., 2018) El conocimiento científico, como se puede constatar, va mucho más atrás del momento mítico formulado por Plinio el Viejo siglo VII A. c. y que aludía al origen de la pintura como obra de una joven de Corinto que pintó la sombra de su amado que una luz proyectada sobre una pared antes de que él partiera a la guerra. Ante la incertidumbre del destino que aguardaba al muchacho, la enamorada decidió capturar y guardar su imagen. El relato es bello, pero ya se pintaba desde hacía siglos cuando los griegos crearon esta explicación. Lo que en cambio sí guarda correspondencia entre la información científica y el relato griego es que las imágenes se producían sobre los muros. No solo los neandertales y los homos sapiens lo hicieron así, sino que las paredes de palacios y templos religiosos fueron el soporte fundamental de la expresión visual en numerosas culturas por muchos siglos durante los que las imágenes visuales estuvieron vinculadas y condicionadas por la materialidad de un soporte estable: la cueva, el palacio, el templo. Pasará tiempo hasta que la pintura encuentre un lugar independizado de la cavidad mural. En definitiva, lo cierto es que lo largo de su historia la humanidad no dejó de producir representaciones visuales dando lugar a lo que llamamos hoy: artes plásticas. Estas artes son las que toman materiales y los transforman plásticamente. En ellas se crea moldeando, disponiendo, esparciendo, aplicando, conduciendo y asegurando diferentes materias sobre una superficie. La plasticidad alude a la cualidad de los materiales cuanto a la actividad de los y las artistas que se sirven de ellos. Desde el arte inicial en las cavernas ejecutado por medio de técnicas como el soplado de pigmentos, el coloreado de huellas, el trazado de pictogramas, el dibujo, la pintura o la creación de petroglifos, las artes visuales estuvieron marcadas por la intervención humana sobre una materia, tarea que se realiza usando el cuerpo, herramientas específicas y materiales con capacidad de fijar, dejar huella o rastro de un trazo. Hay una materialidad inherente al acto de crear imágenes y a la naturaleza de esas producciones visuales que es radical.

La imagen-materia, inscrita en un soporte y pensada como duradera es, al decir de José Luis Brea: "el producto por excelencia de la vida del espíritu, que, frente a la experiencia generalizada del cambio, no se ve afectado" (Brea, 2010:12) La pictorialidad educa a la mirada para buscar en el trozo visible que ha perdurado, el vestigio de una realidad pasada. La imagen-materia, en lo que conocemos, es la originaria y pervive durante toda la existencia humana hasta hoy. Pero ya no es la única.

Fue en el entorno positivista tecnocientífico del siglo XIX que nació la fotografía y, concordantemente con el espíritu de la época y con su naturaleza técnica, fue dotada del prestigio que le correspondía por ser el medio capaz de certificar una escena y también de generar una memoria sobre ella. Como es evidente, la fotografía supuso un paso cualitativo en lo relativo a la materialidad de lo visual puesto que la actividad de quien maneja los instrumentos para generar las imágenes se reduce a disponer del aparato, mirar a través de él y disparar.

El acto de fotografiar descarga al ejecutor de la labor de dibujar y de pintar, libera de la exigencia de una mano hábil a cambio de un cierto tino en la actividad del ojo: el fotógrafo debe saber mirar y seleccionar. Luego, simplemente, disparar. No obstante 
ello, esa actividad dio lugar a imágenes de apariencia mimética, con un realismo sorprendente. Paradójicamente, las imágenes que se producen así albergan una incomparable materialidad que emana de la indudable comparecencia física de aquello o aquellos que son fotografiados. Como vislumbró Roland Barthes, "la fotografía es literalmente una emanación del referente. De un cuerpo real, que se encontraba allí, han salido unas radiaciones que vienen a impresionarme a mí que me encuentro aquí" (Barthes, 2008:126). La fotografía, por tanto, da testimonio de algo que ha tenido lugar y, al hacerlo, lo vuelve a hacer visible. Pero ¿a condición de qué?, de que esa emanación de la realidad material convierta a sus modelos en espectros, que los transforme en luces y sombras.

Si el pintor retrata a unos modelos o pinta un bodegón a partir de un grupo de elementos dispuestos sobre una superficie, sospechamos sin certezas que personas de carne y hueso o que los peces, las frutas y las flores han podido encontrarse allí cuando el artista les daba visibilidad con sus colores, algo bien distinto a lo que implica la emanación lumínica de cuerpos sobre una superficie. Hay en la fotografía un proceso específico de desmaterialización, por tanto, pero hay también una materialidad inédita para el campo de la creación visual puesto que el referente de la imagen fotografiada ha emitido su fantasma de luz que ha quedado plasmado. A este respecto Susan Sontag (2008) observó que las imágenes fotográficas podían llegar a parecer fragmentos de mundo más que enunciados sobre el mundo.

Por otra parte, las imágenes fotográficas y fílmicas obtenidas por medios técnicos tienen la cualidad de ser fácilmente reproductibles y, en tanto tales, capaces de romper con el carácter suntuario y exclusivo que ostentaba la imagen única y aurática producida laboriosamente por un artista. En poco tiempo las imágenes producidas de forma mecánica dieron lugar a una nueva industria que hizo que las imágenes estuvieran potencialmente disponibles para cantidades enormes de espectadores que se integraron en la categoría de público, por ejemplo el público del cine, y que -en tanto tales- podían tener acceso a ellas a cambio de un precio. Esta erogación asumible no los convertía en propietarios de las imágenes sino en circunstanciales fruidores de las mismas. Así, y como resultado de estas nuevas prácticas, creció vertiginosamente una industria creadora de productos visuales para el ocio, y ya no solo para el testimonio.

Con el paso del tiempo y el desarrollo de las tecnologías computacionales, se produjo un nuevo salto que nos sitúa ya en este tiempo del que somos contemporáneos. La digitalización, nueva gran sacudida para la imagen, conlleva una revolución que afecta a lo visual pero también a otra infinidad de ámbitos. Observamos, por mencionar uno de ellos, que en la cada vez más generalizada accesibilidad a las cámaras digitales de foto y vídeo, todos nos transformamos en potenciales creadores visuales, a veces incontinentes, y en ese contexto, el acto perpetuo de hacer fotos y el de grabar imágenes se convierte en muchas cosas diferentes que van desde la diversión al rito social, desde el registro documental hasta la búsqueda de lo más fotogénico. En ocasiones observamos que la imagen queda reducida a una experiencia en sí misma y la experiencia de los hechos queda de algún modo sumergida bajo el peso del constante fotografiar (Sontag, 2008).

Somos coetáneos de una era en la cual el proceso de desmaterialización que implica la tecnología digital nos sitúa ante una nueva paradoja: la imagen que genera puede ser aún más espectral que la imagen fotográfica de antaño. Digámoslo de este modo: no es material de óleo y tela, tampoco es soportada por la sustancia delgada de la película fílmica en la que se fijan merced al revelado químico las luces y las sombras, la imagen digital es inmaterial y es invisible. Si decimos esto es simplemente porque la imagen digital yace como código binario y solo adviene a su faz visible si se accionan los mecanismos computacionales reque- 
ridos. Vilém Flusser sostiene que las imágenes técnicas son imágenes sintéticas o sintetizadas y no tienen igual nivel ontológico que las imágenes tradicionales puesto que éstas son superficies construidas de puntos, abstraídas de volumen. En ellas ya no nos referimos a la bidimensionalidad ni a la unidimensionalidad sino a la cerodimensionalidad, sin nada detrás (Flusser, 2017).

Vivimos en tiempo en el que hay fluidez entre lo online y lo offline. Eso puede producir como efecto que se difuminen en la consciencia ciertas distinciones entre mundo material y el mundo virtual porque todo sucede en simultaneidades temporales en las que las dimensiones se entrecruzan y se mezclan influyéndose entre sí con una agilidad que se asume de una manera muy natural, en ocasiones desapercibida (Ruas dos Santos, 2020). Flusser vislumbra un futuro para la sociedad en la que los intereses de los seres humanos se concentrarán en las imágenes técnicas y vaticina que la sociedad será utópica, es decir: sin topos, carente de lugar más allá de aquel que es el de las "superficies imaginadas" (Flusser, 2017:29) También la dimensión temporal quedará fuertemente alterada en tanto el aquí y ahora dependa en mayor medida de la activación de cada archivo, de cada imagen que hará presente unos contenidos o experiencias en momentos específicos no necesariamente sincronizados con el resto de personas, avanzando así hacia una especie de temporalidad a la carta.

El punto de mayor fractura en lo que concierne a la imagen como representación de la realidad en la era de la " $e$-image" consiste, en definitiva, en que se trata de espectros -como hemos señalado- pero ya no en el sentido indexical al que antes aludimos sino en un sentido más radical: son espectros puesto que son "ajenos a todo principio de realidad” (Brea, 2010:67), son una pura inteligibilidad que sólo se hace evidencia en el momento en el que la imagen aparece por activación. En ese sentido las imágenes digitales serían comparables a las imágenes mentales o a las imágenes oníricas, sin embargo, el recorrido de la analogía es corto puesto que a diferencia de las imágenes que genera nuestro psiquismo, éstas estarían siempre disponibles para ser encendidas y volver a cobrar luz. Además, las e-imágenes se pueden compartir y ser vistas por otros, algo que evidentemente no ocurre con el contenido onírico, salvo que sea traducido al registro lingüístico oral o escrito.

Las imágenes que se visibilizan en infinidad de pantallas conviven en su permanente disponibilidad con otra infinidad de imágenes que no son entre sí excluyentes, como podían serlo las imágenes en los tradicionales medios de masas. Ahora es posible abrir varias al mismo tiempo y hacerlo además en la misma pantalla. Cada usuario hará con ellas sus propias activaciones, combinaciones, simultaneidades, sucesividades, etc.

¿Cómo pensar las imágenes en tiempos de pantalla total, de desmaterialización del locus, de ubicuidad de unas imágenes que yacen en latencia insustancial hasta que un beso las despierta en cualquier pantalla? Esa ubicuidad y al mismo tiempo la capacidad para activarse y desactivarse a causa de la esencial inmaterialidad de su existencia en tanto archivo de imagen, de su descorporalización telemática, de su existencia fuera del espacio material-ontológico, debe necesariamente hacernos replantear una vez más nuestra idea de la realidad en relación con la definición de lo que una imagen es. La imagen digital ya no tiene una cita en un lugar ineludible como sí lo tenían la imagen-materia y la imagen-huella. Esta potencial capacidad para hacerse siempre presente permite a la imagen digital-archivo no sólo salir de la lógica cultual de la obra de arte original sino que también la aleja de la imagen de la era indexical.

Como es sabido, el lenguaje de la programación con el que se ejecutan las imágenes digitales es matemático, las imágenes se hacen con números y pensamientos lógicos. Sus nuevas tecnicidades permiten un grado de realismo equiparable al de las míticas uvas pintadas por Zeuxis, pero a diferencia de aquellas, estas uvas son tremendamente maleables mediante la activación de las 
interfaces y los softwares, tanto que los espectadores pueden hacer con ellas cosas que no eran posibles antes: jugar con las uvas, copiarlas y pegarlas, editarlas, ponerles filtros, compartirlas, etc. (Machado, 1998)

Añadamos ahora a este escenario lo que ha dado en llamarse: realidad aumentada. La realidad aumentada es el resultado de la integración de diversas tecnologías que permiten tener experiencias entre cuerpos y hologramas en una interactividad fluida. En Corea del sur, por citar un caso que fue muy mediático, se produjo un gran debate público como consecuencia del empleo de tecnologías de esta naturaleza que, mediante la incorporación de dispositivos digitales wearables (gafas y guantes especiales) permitieron a una madre ver a su hija fallecida, conversar con ella, acariciarla. El encuentro se retransmitió por televisión suscitando emociones y debates fuertes. Estamos ya en los albores de un tiempo en el que la tecnología permite crear ilusiones a veces realistas e incluso hiperrealistas, que nos sitúan en la puerta de entrada de espacios donde se hace efectiva la interacción entre el mundo físico y el virtual, una suerte de realismo de lo inexistente. Todo ello nos plantea nuevas dimensiones de realidad.

Es muy probable que el futuro nos depare aún nuevas experiencias en las que las realidades materialmente imposibles se vuelvan practicables por medios virtuales con una alta potencia de veracidad, con una ficción de tridimensionalidad y con capacidad para generar emoción, reacción y también conocimiento. Ciertas imágenes sintéticas no necesitan pretender que representan el mundo pero, irónicamente, juegan en la frontera de la similitud y la incertidumbre y es eso lo que parece hacerlas tan potentes. Ejemplos tan populares como la cantante-holograma llamada Hatsune Miku cuya imagen se proyecta en escenarios y concita reacciones de euforia en su público humano que asiste pagando su entrada a una sala de conciertos o un estadio es solo otro ejemplo más de ello.

Evidentemente, y así ha sido profusamente señalado, cada nuevo régimen de visualidad trae aparejada una nueva sensibilidad expresiva, una nueva posición para quien mira, unos estándares estéticos que deben ajustarse, y una nueva modulación para el concepto de imagen: "los nuevos medios cambian nuestro concepto de lo que es una imagen porque convierten al espectador en un usuario activo. En consecuencia, una imagen ilusionista, ya no es algo que un sujeto se limite a mirar y que compare con su recuerdo de la realidad representada a fin de juzgar su impresión de realidad. La imagen de los nuevos medios es algo en lo que el usuario entra de manera activa, haciendo un zoom de aproximación o haciendo clic en partes concretas, sabedor de que contiene hipervínculos (...) Los nuevos medios convierten a las imágenes en imagen interfaz e imágenes instrumento. La imagen se vuelve ahora interactiva, es decir, funciona ahora como una interfaz entre un usuario y un ordenador u otros dispositivos" (Manovich, 2005:245).

Quizás, esta nueva naturaleza de lo visual, consecuentemente con su arquitectura, nos sitúe ante el fin de la imagen que mira al mundo, de aquella que se presenta como espejo o ventana. Más aún, podríamos estar el fin de la era de la imagen-reflejo, aquella que en su fuente era generada por efecto de la luz (Brea,2010).

\section{Conclusiones: ¿qué realidades?}

Un aspecto que no hemos mencionado aún y que conviene recordar es que no todas las imágenes son de la misma naturaleza. Si consideramos las imágenes desde la perspectiva de los fines, es lógico que no se espere lo mismo del fotoperiodismo, por ejemplo, que del arte. En el primer caso su bien hacer se valorará en términos de su incuestionable lazo con los hechos que se van a presentar puesto que hay una realidad fáctica que debe ser registrada y comunicada, y la mayor fidelidad posible forma 
parte de los códigos deontológicos que rigen las prácticas informativas. Muchas imágenes periodísticas tienen además un valor técnico y visual innegable. Existen premios institucionalizados que consagran el acierto, la oportunidad, la elocuencia, el valor testimonial, la novedad temática e incluso estética de las fotos informativas. La imagen informativa es quizás uno de los ámbitos de lo visual más sujeto a la exigencia de exactitud, de espejamiento.

En cambio, el campo artístico puede manejarse y se maneja con unas metas bien distintas. Martin Gayford dice que "las imágenes son una forma de representar el mundo, y también de entenderlo y de examinarlo, es decir, una forma de conocimiento y un medio de comunicación. Es mucho lo que podemos aprehender en un instante a partir de una imagen. Ahora bien, ¿qué nos muestran? ¿Realidad o ficción? ¿Verdad o mentira?” (Hockney y Gayford: 2018:19). ¿Es necesario saberlo? Si hablamos de arte el dilema se desprende en buena medida de su injundia.

Para Paul Klee, por ejemplo, el arte no es lo que reproduce lo visible sino que es aquello que hace visible, y para David Hockney la imagen es aquello que añade importancia a lo representado, lo que subraya su relevancia y, en consecuencia, no es una representación de la realidad sino una mirada sobre la realidad. Como suele afirmarse, si bien la imagen ostenta la potencia de permitirnos entender el mundo o descodificarlo, el artista será aquel capaz de sostener un espejo ante la realidad para luego proyectar imágenes ilusorias de ella. En una entrevista Alberto Giacometti expresó lo siguiente: "estoy persuadido de que sólo es pintura aquello que es ilusión. La realidad de la pintura es la tela, que es realidad. Pero una pintura solo puede representar lo que no es, es decir, la ilusión de otra cosa" (Giacometti, 2015:293)

Al referirse a la abstracción en el arte, el pintor estadounidense Robert Motherwell, sentenciaba que su función es justamente la de deshacerse de la realidad; en consonancia, en `Manifesto’, película-ensayo sobre el arte de Julian Rosefeldt (2015) se dice que el arte contemporáneo ha salido del círculo de los objetos y que en él los objetos se desvanecen como humo. Como es posible apreciar en este puñado de referencias, la relación entre la imagen y la realidad es planteada en el arte desde múltiples perspectivas, todas ellas sorprendentes y productivas poniendo en evidencia que la realidad del mundo de las cosas y los hechos o su representación no es una meta ineludible, ni preferente, ni rechazada, ni abrazada. ¿De dónde procede el afán por encontrar lo real en las imágenes?

Eliseo Verón explica que, a la luz de la modernidad, y con la disponibilidad social de soportes tecnológicos complejos de comunicación, emergió una discursividad que ha sido abordada en términos de "concepción representacional” (Verón, 2001:13) merced a la cual la sociedad mediatizada necesita poner una frontera entre aquello que ocurre en el escenario de la vida y lo que transcurre en los cada vez más presentes y múltiples medios de comunicación a través de los cuales la sociedad se informa y se comunica, pero también en los que la sociedad es presuntamente reflejada.

Cuando Susan Sontag publica su libro "Sobre la fotografía" corre el año 1977 y ella se interroga allí sobre el "ensanchamiento del abismo entre imagen y realidad" (Sontag, 2008:121). Ante esta intuición propone la siguiente idea: que toda imagen genera una alienación de la realidad en tanto que la recorta, la subraya, la descubre, la transforma. La imagen, por tanto, sería en sí misma una forma de separación. Sabemos que en las culturas tradicionales, la diferencia entre imagen y realidad no es abismal puesto que la imagen y la realidad son dos manifestaciones de la misma cosa o energía y, en cierta medida, de ello se deriva la eficacia de las imágenes. Como apunta Regis Debray, “magia e imagen tiene casi las mismas letras” (Debray,1994:31) por eso, el separar a la imagen de lo real forma parte del proceso de desacralización que ha tenido lugar por siglos en el mundo llamado occidental. El 
símil generado por las imágenes de producción mecánica restituyó, al menos por un breve lapso y de forma relativa la aparente identidad entre imagen y objeto aunque haciéndolo a la inversa de los tiempos antiguos: en muchas ocasiones atribuyó a las cosas reales las propiedades de las imágenes y no la inversa.

Las transformaciones sociales que atañen a las formas de mediación crean espacios imaginarios, son fuente de sentido y establecen una nueva economía de la mirada. En la contemporánea era digital, cuando la mediación tecnológica abarca mucho más que la mera exhibición de contenidos elaborados con la pretensión de referir a realidades que tienen existencia en el universo material de la vida, lo que se puede hacer ya es bastante más que re-presentar. Y a estas alturas parece legítimo preguntarse si el hecho de vivir en una sociedad tan visual no acaba transformando nuestra idea misma de realidad.

Si salimos de estas esferas y ponemos un ojo panorámico sobre los múltiples estados actuales de lo visual, podemos legítimamente presentir que las e-imágenes pueden ayudarnos a ver pero también pueden sorprendernos y descolocarnos. Basta con visitar una exposición de arte digital para experimentarlo. También podremos, por ejemplo, ser conducidos por un coche virtual hasta el corazón de una geoda que en la realidad es de acceso prohibido o materialmente inaccesible, y sentiremos en la piel y en los nervios que ese viaje virtual puede resultar más emocionante para el cuerpo que la visita efectivamente realizada al borde de la cavidad escondida en el interior de la roca. En ocasiones, la imagen más que representar unas realidades, nos transportan hasta donde no es posible, crea universos, penetra virtualmente en lo impenetrable y nos lleva con grandes sensaciones corporales justo hasta allí adonde no podríamos estar, a lugares que ya no existen o incluso que no existieron jamás.

Por ahora, en lo que a la población en general se refiere, las dimensiones lúdica y social parecen ser las más frecuentadas de la imagen y, sobre todo, el hecho de hacer fotos y vídeos se ha convertido en una gestualidad cuyo valor se impone muchas veces sobre el sentido. El tic de hacer fotos de casi todo se complementa con el hecho de que la circulación de las imágenes ha adquirido una gran fuerza y, esa disponibilidad también le concede un valor vertiginoso y perpetuo contribuyendo a la secundarización del valor del contenido.

El fotógrafo y ensayista Joan Foncuberta (2016) advierte sobre el exceso de imágenes, una especie de antiecología alentada por la facilidad para fotografiarlo todo y publicarlo que genera una repetición de lo idéntico y una dificultad o indiferencia para mirar que es sepultada por la pulsión fotográfica individual. Las miles y miles de fotografías de atardeceres en la naturaleza que han sido tomadas ya no significan porque a lo que se aspira es a la foto del atardecer vivido en primera persona, al testimonio de la experiencia personal. La foto es casi irrelevante más allá de la supuesta constancia que aporta: yo estuve allí. Yo estuve allí se vuelve importante como marca de una experiencia, pero es un tipo de experiencia que en ocasiones está más volcada hacia la exhibición que al aspecto vivencial: la foto puede ser embellecida, retocada hasta el desconcierto con el propósito de provocar un efecto. Yo estuve allí, en lo más espectacular. Ergo, sum. Una vez compartida se tornará pronto indiferente, puro residuo, chatarra digital. La visibilización de todo podría tener un efecto paradógico: por un lado se produciría "la desaparición de lo invisible” y, en consecuencia, la disponibilidad de lo visible podría generar una especie de "nada vale" (Debray,1994:305/6), o quizás también un "todo vale".

Veamos un caso cercano: en estos tiempos cuando una pandemia aqueja globalmente a la humanidad, con medidas sanitarias, sociales, económicas, con cifras de infecciones y de muertes; en tiempos en los que la ciencia habla en los medios de comunica- 
ción porque la ciudadanía necesita comprender y necesita orientación, no dejan de surgir, sin embargo, grupos negacionistas. ¿Cuán pesada ha de ser la realidad para acreditarla? ¿cuáles son los instrumentos para corregir las opiniones infundadas?

Ante cierta laxitud en los comportamientos sociales, se formula una sugerencia: que los medios informativos publiquen fotografías que certifiquen el estado de los hospitales, que muestren lo que implica un paciente intubado, el agotamiento de los trabajadores de la sanidad, etc. Se espera que las imágenes, con su arrolladora fuerza de realismo, desmientan a los falsificadores de la realidad. La reacción no se hace esperar y prestamente comienzan a aparecer publicaciones en redes sociales de carácter negacionista con fotografías que pretenden ser probatorias de lo contrario: salas de ingresos vacías, pasillos calmados, sanitarios sonrientes y relajados. La policía recibe el cometido de detener y multar a los difamadores.

En definitiva, estos argumentos nos permiten anudar y desanudar el hilo temático que vertebra este escrito, y necesitamos hacerlo porque el carácter representativo y la alusión a la realidad requieren infinidad de precisiones, discusiones, y porque es un asunto que parece afectar a nuestro modo de estar en el mundo, en las cosas, en nuestra propia existencia. Las concepciones de imagen y realidad no son extrañas entre sí y ambas cambian acompasadamente. La consciencia sobre la provisionalidad de los planteamientos es patente puesto que nos referimos a fenómenos en permanente ebullición.

\section{Agradecimientos}

El artículo ha sido traducido por Ann Merry.

\section{Referencias bibliográficas}

Barthes, R. (2008). La cámara lúcida. Nota sobre la fotografía. Buenos Aires, Argentina: Paidós.

Belting, H. (2007). Antropología de la imagen. Buenos Aire, Argentina: Katz editores.

Brea, J.L. (2010). Las tres eras de la imagen. Imagen-materia, film e-image. Madrid, España: Editorial Akal.

Debray, R. (1994). Vida y muerte de la imagen. Historia de la mirada en occidente. Barcelona, España: Paidós.

Dubois Ph. (2008). El acto fotográfico y otros ensayos. Buenos Aires, Argentina: La marca editora.

Flusser, V. (2017). El universo de las imágenes técnicas. Elogio de la superficialidad. Bienos Aires, Argentina: Caja Negra.

Gubern, R (1999). Del bisonte a la realidad virtual. La escena y el laberinto. Barcelona, España: Anagrama.

Foncuberta, J. (2016). La furia de las imágenes. Barcelona, España: Galaxia Gutenberg.

Giacometti, A. (2015). Escritos. Madrid, España: Editorial Síntesis.

Gombrich, E. (1999). Meditaciones sobre un caballo de juguete y otros ensayos sobre el arte. Madrid, España: Debate.

Hockney, D. y Gayford, M. (2018). Una historia de las imágenes. Madrid, España: Siruela.

Hoffmann, D. L., Standish, C.D., García Diez, M., Pettitt, P.B., Milton, J.A., Zilha Alcolea Gonzáles, J.J., Cantalejo Duarte, P., Collado, H., de Balbín, R., Lorblanchet, M., Ramoz Muñoz, J., Weniger, G., Pike, A.W.G. (2018). U-Th dating of carbonate crusts reveals Neandertal origin of Iberian cave art. Science, 23(359), 912-915. Artículo 637. DOI 10.1126/science.aap7778 
Machado, A. (1992). El imaginario numérico: simulación y síntesis. Revista Acta poética 13 (1 y 2), 55-76. https://revistas-filologicas.unam.mx/acta-poetica/index.php/ap/article/view/515/519

Manovich, L. (2005). El lenguaje de los nuevos medios de comunicación. La imagen en la era digital. Barcelona, España: Paidós. Ripoll Perelló, E. (1986). Orígenes y significado del arte paleolítico. Madrid, España: Silex ediciones.

Rosefeldt, J. (Director) (2015). Manifesto; [Película] Bayerischer Rundfunk(BR), Ruhr Triennale, Schiwago Film.

Ruas do Santos, F (2020). O velho mundo da pintura, o novo e o pós-mundo. Roteiro de viagem audiovisual em $3^{\circ}$ tratamento. [Tesis fin de carrera no publicada]

Sontag, S. (2008). Sobre la fotografía. Barcelona, España: De Bolsillo.

Verón, E. (2001). El cuerpo de las imágenes. Buenos Aires, Argentina: Grupo Editorial Norma. 
